\title{
COMPOSITION OF PERMANENCES IN URBAN LANDSCAPE. PLAN FOR SAINT-DIÉ 1945-46
}

\author{
Fabiola GORGERI \\ University of Florence, \\ Via Larga n.145/d6, Quarrata, 51039 Italy \\ E-mail:fabiolagorgeri@hotmail.it
}

Received 14 November 2015; accepted 07 April 2016

\begin{abstract}
The relationship between new and existing in urban design is considered by Le Corbusier an opportunity for poetic composition through sequences of visual frames. The public space constitutes the connective tissue and the measure of perceived distance. The buildings are curtains and visual horizons in the territory: they can define the space in which the collective urban scene takes place.

Project of soil and perceptive paths allow a paratactical composition of pieces, assembled according to the calibrated balance of spatial proportion; organic dynamicity of the nature and geometric sign refer both to the physical location of the settlement and baggage of historical references culturally shared.

From the forties and after Second World War, the urban projects focus more on the consolidated city, or fragments of it, seeking a line of historical continuity with pre-existing environment. There are three kinds of permanences: the geographical aspects, the historical aspects derived from the specific territory and the cultural mnemonic references. So, the plan for Saint-Dié is an expressive example where the city is designed adding analogous shapes: a landscape, an atmosphere, where buildings and environmentterritory resonate mutually.
\end{abstract}

Keywords: Le Corbusier, urban history, public space, landscape, territory, Saint Dié.

\section{Introduction}

"The history is an uninterrupted flow" (Le Corbusier 1925: 92) in the time and through places.

There are many and different ways to assure permanence or changing in architecture.

In flowing of the time the shapes are a kind of permanence: they allow continuity and transmissibility of the human work and in specific of the architectural work.

The void is a particular kind of the shape: it is like a fluid and it needs a box or any delimitations for having an appearance and assuming an aesthetic value.

The void is as the silence and allows the becoming of things: it is the place where any relationship become possible. It is precisely l'êntre, that allowing the narrativity of the urban design according to several temporal distances: solar time, time of the perceptive paths and historical time.
For Le Corbusier, this urban narrativity represents a way to consider the time like a material of the project: a design methodology to include the human life in it.

The path of the sun - the solar day - suggests orientation of buildings and times of their daily use as well as the intermediate space between interior and exterior, characterizing their surfaces.

Time-distance is a unit of measure on which the project is set dimensionally: the journey time on foot is the dimensional scale that primarily regulates the distance between the buildings connected by reciprocal functionality.

This measure, that in French Le Corbusier defined "temps-distance" in his writings about the city planning and the ways of dwelling, like in Manierè de penser l'urbanisme (Le Corbusier 1946f), is a dynamic unit connected to other urban functional units. In particular, it establishes relationships between residential unit 
and its extentions, both material and spiritual ones, for example educational places, or with the working unit: the correlation between time and space, but also different concepts of duration, temporality and temporary nature, are understood by this compound word.

This path of time and distance is also thought as a promenade architectural that puts ensemble and joins the different pieces of the urban scene. The pieces - the buildings and the relative void - are at the same time fragments of a larger whole that they themselves evoke or to which relate, and calculated visual frames of a designed landscape.

The urban unit, as a kind of plastic unit, is obtained by juxtaposition of different things and through a paratactic composition. In this way of thinking about the urban reality and the urban design, the historical temporality is like an implied process without a specific referring to a strict philological time. The history is understood above all as the identity of a place: it is present in traces and elements often became also geographical signs in the territory. So, it is also social history.

The monumental building is representative of a community of people as well as the main square is the agora for the social and political meeting. The traces of the past are often the lines with which to reconnect the urban settlement to a primitive order of nature. The traditional shapes, implied in the shared culture of a community, are reinterpreted in according to a process of abstraction that reduces them to the essentiality like pure volumes and proportional void.

Therefore, geometric order and organic dynamicity of the nature are present together in the urban design as expressions of harmony that Man establishes with its environment. These aspects became more important around the forties and especially after the Second World War.

\section{Urban design and heart of the city}

The project of the reconstruction of the city of Saint Dié des Vosges, par example, is a "prototype" (Le Corbusier 1946c: 132) for many subsequent projects.

Saint Dié is not a big city, but the environmental contest where is located allowing to link it to the geographical territory and to assume it as an important pivot in the regional scale.

The almost complete destruction of the city, on November 1944 by German troops, revealed a system of permanent signs and unexpected relationships with the geographical contest.

The new reality disclose the territorial background like a permanence: a structure by which the city have been generated and remain anchored for its future changes.
[...] La destruction à peu près complète de l'anciènne ville a eu comme effet de dégager et de remettre en valeur le paysage environnant qui est agréable et charmant. C'est une révélation pour le visiteur et plus encore pour l'habitant.

Trésor retrouvé! (Le Corbusier 1945a)

In the landscape of rubble, only the cathedral at north and the religious complex beyond the river as well as the building of railway station stand still up, connected visually and physically by the main street.

The urban design for the reconstruction of the city, developed from April 1945 to February 1946 (Le Corbusier 1945a; 1946a; 1946d; Musée de SaintDié 1987; FLC H3-18), reads the historical urban traces that are also the main geographical signs: the river, the mountain on the background and the main street. Latter is also the main and right sign of the first settlement around which the whole city has grown: it is as a structural and founding trace. The churches and the station are also monumental buildings representative of the history of the community: they are signs of local and also territorial identity. All these fragments are not ruins of the past but, primarily, permanences for the future time. They are the durable pieces that become the permanent structures of identity; a kind of "structural invariants" (Secchi 1989) to which the new project can refer. So, existing and new buildings originate by the same basic reference: the territorial context. The urban design brings a constitutive order able to give unity to a heterogeneous ensemble of existing and new objects.

The first sketches for the reconstruction project reveal (FLC H3-18) a reading of the city at a geographical scale: the city is an iconic nucleus and a fulcrum present in the landscape between river and mountains. Then, the attention is focused to the "heart of the city" and on what the remained traces of it may suggest. This reference to the city center as the pulsating heart of a living organism is a coherent image of the poetic reflection of Le Corbusier also before the CIAM 8 of 1951 on this topic and with the same title (Rogers et al. 1954), from Urbanisme (1925) to Propos d'urbanisme (1946).

However, memorials and identity values are more heartfelt after the destructions of World War II. The functional aspects set out from Charter of Athens aren't more enough to respond to new social and urban complexity. An essay like "Nine points of monumentality", written in America in 1943 by J. L. Sert, F.

\footnotetext{
1 [...] The almost complete destruction of the old city has had the effect of relieving and redevelop the surrounding landscape which is nice and charming. It is a revelation for visitors and dwellers. Rediscovered treasury!
} 
Léger, S. Gieidon (Sert et al. 1943) who were members CIAM and collaborators of Le Corbusier, highlights the importance of a new kind of monumentality born by collaboration of architects, artists and landscapers. As in the $8^{\text {th }}$ point of it, the new urban center has to put attention to the large scale and the open spaces where the lyric value of the monumental architecture, more than strictly functional, can find its appropriate setting like landmark in relationship to an specific territorial environment. The project of Saint Dié is a kind of eloquent application of these points. So, the remains of the past are considered for their immaterial, intangible and abstract value. The three remaining fragments of the existing city and the traces of settlement, in particular the main street like an ordering axis, are the constituent pieces on which the whole composition is innervated within the context itself (Fig. 4).

The heart of the city and so of the whole plan is the civic center occupying the old city center. This core keeps also the simultaneous presence and the usual relationship between civic space and religious space peculiar of medieval centres.

The monumental and identity buildings are a kind of isolated objects with their autonomous plastic shapes able to excite. The different buildings, like architectural objects trouvé, are held together through the sights according to calculated paths of perception: thus, even the fragments of the past are reinstated and safeguarded for their social and poetic value rather than preserved in a precise outright "state of fact".

Already in the Voisin Plan (1922-1925), project for a business city in the center of Paris, some monumental buildings were preserved and placed in a new harmonious context in the middle of the green where the past could so find its own placing (Le Corbusier 1925: 194196). «In the case of the Voisin Plan for Paris, provision is made for preservation of the more important existing monuments and buildings, and for their incorporation in the scheme» (Etchells 1987: XVI). Later, in the plans of thirties, like for Boulogne sur-Seine (1938), he gives more attention to the existing urban fabric which is recovered as connecting element as does the green; also in the large scale plans, like for Buenos Aires (1938), the existing urban pattern is also an integral part of the spatial solutions (Cappiello 1989).

The transformation of the city is carried out through a process of integration purely "organic": like interaction and assimilation between new and existing parts.

The attention on the urban pattern related to the presence into it of monumental objects (Leggieri 1989) defines the measure of urban transformation and the importance of the architecture or the influence at- tributes to the autonomous buildings with their own "space of irradiation".

Nevertheless, in the project for Saint Dié, the presence of the history with its traces is more deep: above all about the civic core of the city. It is a composition of architectures as several and different pieces where the historical aspect is not the only priority but anyway an intrinsic material. For Le Corbusier, the history is dialectical, returning to the past to reassess it (Gans 1999). His idea of history is as a living tradition and describing an unmediated existence in touch with nature: the project is a possibility to restore «the relationship between material progress and natural elements of a spiritual life» (Le Corbusier 1961a: 13). The new urban design research a regular order "of nature" including existing signs of historical topography and considering the geographical location.

So, the whole project is a paratactic composition organized on the basis of a geometrical but flexible grid of repeated squares where geometry and nature coexist and «[...] have often been the support of touching things [...]» (Le Corbusier 1941: 48).

In particular, the cathedral and the other church are two nodal objects united by the main urban axis and around which the other new elements are located according specific unité. The unité are a kind of guide for the urban planning in an area not delimited. The city is into an opened context linked to the geographical and territorial dimension: it is not morphologically bounded but opened to new developments.

The unité are both concepts, areas and buildings.

There are different unité for each function characterizing urban life (Le Corbusier 1946f; 1945b) and first of all for dwelling. According to the principles reflected in the Charter of Athens, around the main function of dwelling there are the other ones to work, enjoy the free time and circulate. The whole plan of Saint Dié can be divided into horizontal registers that identify functional areas, which are all referred to the central area and dimensioned according walking distances. The scale of project is the human walking, the right distance between housing and working and the right dimension of the voids between volumes for the good perception of themselves. The productive area is located beyond the river, in a no destroyed zone of the ancient city. With the line of river, the unité de travail constitutes a visual and morphological limit like a sign of urban walls and fortifications. The rests of the ancient church and of the rail station are included in this zone and they are like main points of connection with the rest of the city. L'unité d'habitation, in particular, is an ideal vertical town: many aspects of historical urban 


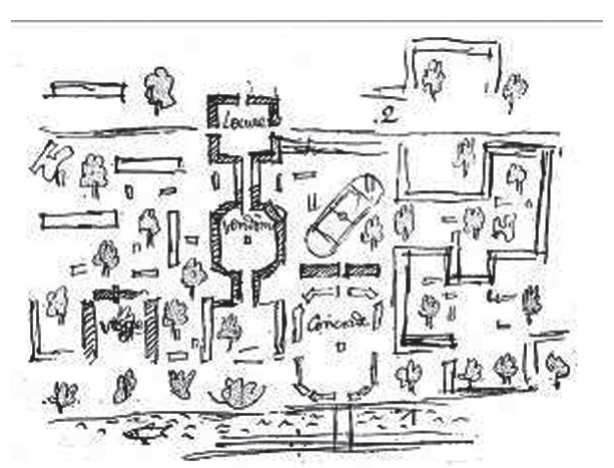

Fig. 1. Composition of parisienne squares in sequence with new buildings and green areas. From Le Corbusier, Le Corbusier 1946, Propos d'Urbanisme, Paris: éd. Bourrelier \& Cie [Perspective humaine]: 113

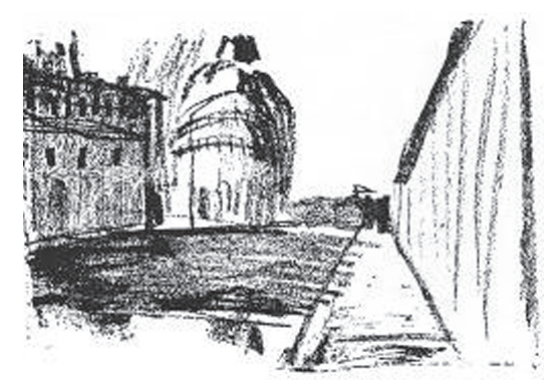

Fig. 2. Piazza dei Miracoli in Pisa. From Le Corbusier 1960, Mein Werk, Stuttgart: Verlag Gerd Hatje: 41

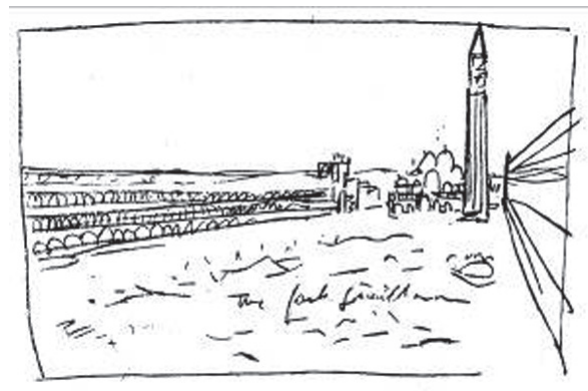

Fig. 3. San Marco square in Venice. From Le Corbusier 1946, Propos d'Urbanisme, Paris: éd. Bourrelier \& Cie [Perspective humaine]: 17

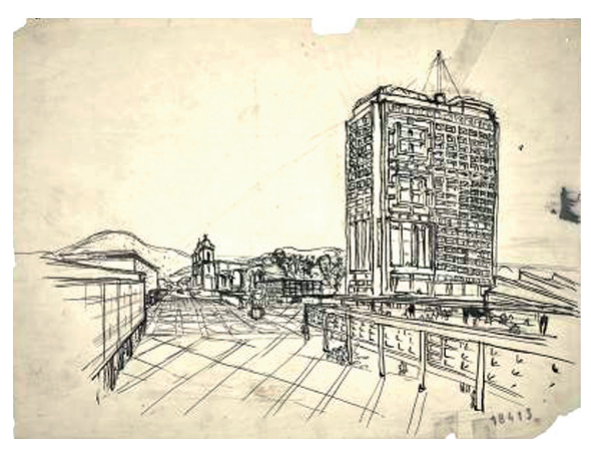

Fig. 4. View through the main axis, old main rue Thiers, with the cathedral, the admistrative skyscraper and the mountains on the background. Le Corbusier, Scketch August 1945.

From Musée de Saint-Dié 1987, Le Corbusier et Saint-Dié, SaintDié: Musée municipal de Saint-Dié: 105 morphology are interpreted and adopted to create also these new typologies.

The corridor-streets, for example, become interior corridors in the unité d'habitation: it allows to reach the dwelling cells and to create public spaces inside the building improving quality of social life.

This transposition of typological forms, implicit also in the conquest of the height and especially about the house, changes the relation of latter with the whole city: the house attains the symbolic aspect and the dignity of monument through its shape and dimension.

This change of a meaningful morphological aspect can get social transformations so that also the evolution of society toward harmony would thus be mirrored by that of architecture (Vidler 2010), above all of public spaces.

Architecture and urbanism are at the same time tools and expression of human life so also of society.

Other aspects of this urban composition refer directly to the historical examples: some open space of the cities of the past are evocated in the new public spaces and in the relationship between public and private space (Fig. 1).

The past is master and a constant guide (Le Corbusier 1961a: 56) and the memory is a box of tools to design the new town. The history is used also thank and through mnemonic images, combining them almost by a Warburg method.

The frames of visited places back in the projects as experienced sensations and morphological fragments: Piazza dei Miracoli in Pisa (Fig. 2) and San Marco Square in Venice (Fig. 3) are two specific examples.

The balanced disposition of architectural objects on a green carpet of Piazza dei Miracoli is an urban reference for new projects. So, also San Marco Square, with the repetitiveness of the continuous fronts of the palaces, the specific intermediate space between inside and outside of the fronts themselves and the particular relationship of open spaces which they generate is a constant reference.

The repetitiveness of the continuous fronts is recalled in the mind also by some squares of Paris like Place Vendôme and Place des Vosges.

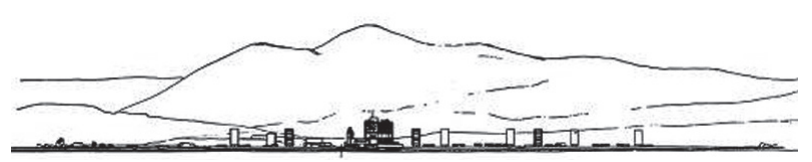

Fig. 5. Skyline of Saint-Dié in the landscape showing the building of the first and second phases. From Le Corbusier 1946, OEuevre Complete. 1938-1946, Zürich: Girsberger: 134 
With a sort of the inter-scales process, they are also urban interiors inside the city.

In the specific project for Saint Dié the reference of the Italian square of Venice is explicitly confirmed on documents of project like a important example of civic center and for the particular relation between public spaces and private spaces of whole city.

In Venice, the two areas have never really defined and the spaces of the threshold are always characterized by a nuanced ambiguity. So that, the whole city can be considered an unique civic center, transliterating private space in public space, the house in the city, and vice versa.

The mnemonic reference is not only about morphological aspects but also, and perhaps above all, about the singular atmosphere of a place.

By an abstraction process the frames from memory are translated in geometrical signs and proportional relations according to the specific site of project.

The urban project is designed as a harmonic symphony whose notes are «the laws of the sun; the site; the topography; the scale of the undertaking; the exterior circulation which reveals the nature of the building; its interior circulation: the infinite resources given us by technical inventions [...]; the new materials [...]» (Le Corbusier 1961a: 52), but also the personal memory. It results also a composition of analogical shapes and logical connection where the studied axiality and intermediate spaces guide the urban experience. The image of the archetypal city with dual axes, a regular grid, formal entrances and a hierarchical importance of a central core is interpreted and juxtaposed ideally as a conceptual layer and used together to the other several functional and perceptive layers.

After some design versions, the final proposal on January 1946 for the urban core is designed around two axis north-south and two visual focus: one axis links the church at south to administrative hide-rise that become the main visual background the other one parallel at first, focus on the cathedral through the cultural area and a sequence of voids, compressed and dilated (Figs 6, 7). This biaxial disposition sets up the urban heart by the connection between civic nucleus and religious nucleus like in a historical town.
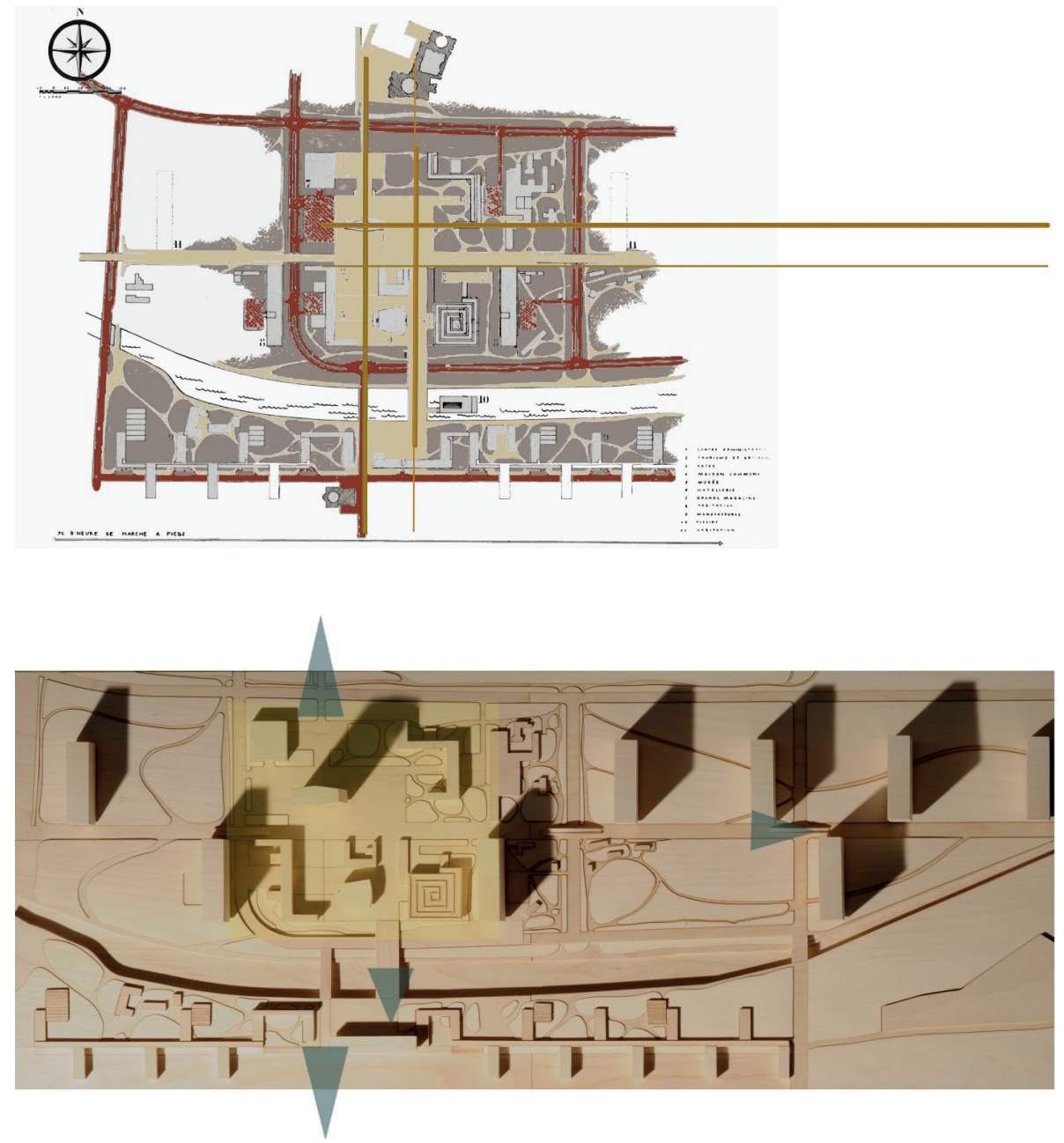

Fig. 6. The civic centre of Sant-Dié, Last version of 1 January 1946. Reworking from Le Corbusier 1946, OEuevre Complete. 1938-1946, Zürich: Girsberger: 139. In red colour vehicular routes; in cream colour pedestrian areas. In yellow colour: main visual axes and meshes of geometric grid
Fig. 7. The civic centre of SantDié, Last version of 1 January 1946. Birch wood model, 1:1000, original $\mathrm{cm} 73 \times 34$. Laboratory Model of DIDA - Unifi, Italy. In blu colour main optical cones 
The different areas are connected in continuous and the buildings are always traversable: the city is designed like a porous place with public spaces connected in sequence.

"The city returns to have axes like all architectural works. The architecture integrates itself with the urbanism and urbanism integrates itself with the architecture" (Le Corbusier 1925: 271). "The city planner is nothing more than the architect»: architecture and urbanism contribute together to create a new unit, a «unite of conform dimension" (Le Corbusier 1997: 55).

In the Le Corbusier's urban design there is also a reciprocal and inter-scale relationship between architectural and urban design. He makes a kind of transposition of architectural shapes in the urban shapes and vice versa: the urban elements are used to design large size buildings, or better "city-building".

In this way, also inner space and outer space change the usual aspect and so the public areas.

The transposition of scale is a way to integrate different activities and transfer aspects and measure of human life in the big building and in the areas of settlement within a territory not more delimited.

Through urban spaces "[...] the scene changes with each step and is never repeated; the corridor-street is gone and is replaced by a scheme where space and an infinite architectural variety are possible" (Le Corbusier 1925: 134).

There is a real "paradigm of Corbusierian sight" (Croset 1987: 4) operating from the observation to the design through the imagination: "this is the key to look/observe/see/imagine/invent/create" (Le Corbusier 1963), to carry out operations of "formal alchemy", associations, compositions and mixtures (Colli 1987).

The sight of Le Corbusier is directly related to a constructive and artistic thinking by which he interprets every observed thing as if it were an object à reaction poétique.

The point of view is important like the object itself and it is the unit of measure referred to the perceiving subject and so to the human life. The views are essential also for the approach to designing, to the project setting: both aerial or zenithal views and views through the walk path are considered present during the design choices. New aerial views allow to consider above all the relationships between the architectural objects, so that both domestic spaces and urban spaces, are linked by zenithal view as their orthogonal projections on a plan (Tamborrino 2003).

At the same time, the views during walking are considered essential in the designing of the public urban spaces. The buildings are composed like a collage and a sequence of visual pictures: buildings and void spaces between them are like frames of a filmic sequence.

The movement is another important component of the urban composition: the slow movement of the walker and the fast movement of the cars and other vehicles are considered always separated and also in different plans and layers.

"Good architecture is walked through and traversed inside as well as outside: that is living architecture" (Le Corbusier 1961a: 47). Also "[...] a road is a plastic event within nature" (Le Corbusier 1941: 48).

"Trasparency" and circulation are essential to connect the pieces of composition: the urban place is a kind of "open work" (Eco 1962) where the subject creates always new different perceptions.

In the plan for Saint Dié the aspect of the circulation is an element that constitutes setting of the whole project (Gerosa 1978). As in the other previous plans, and in particular la Ville Radieuse (1932), in addition to the sharp division between the different systems of circulation there is the mutual independence between buildings and roads and the ground is an ideal plan where the buildings are located.

In the Saint Dié project, the system of vehicular traffic creates the connections with the territorial communication system and at the same time defines the limits of the urban center like new urban walls.

The separation of road infrastructures from pedestrian zones is useful to design the city by areas and systems and without defined perimeters of it so that each part can "resonate" in the each other and develop during the time.

This is one way to restore a better quality of everyday life, social and working. The distances home-work are measured in time of walking distance. The activities of social life and representative of the urban community are concentrated in the urban core which is a sort of pedestrian island opened and connected at the context: pivot in the landscape and theatre of social urban life. In a certain way, the infrastructures define the urban space itself. The connection system links the urban space with the around environment, second hierarchy and dimensional rules that are bonded to speed and time of going, and establishes a grid with measures that order the whole without perimetral limits. Inside this geometrical order, "music of numbers that rule spaces and daily behavior" (Le Corbusier 1951: 451), better defined "Règle des 7 Voies" (Le Corbusier 1945b) with their "sectors" and the $4 \mathrm{~V}$ last ones related to the pedestrian, the urban street is rediscovered like a social place and the quality of voids plays an important role for the quality of urban life. In this interrelation between rules 
and flexibility, the landscape is itself an infrastructure: it is a fluid - of green, air, sun - that crosses the urban site and "irrigates" the territory.

This composition allows to re-establish originating sympathetic relations between Man and nature and returning to principles of urban life referred to the historical city in a time before the "mechanic period", like were its classical space of agora or the urban interior of medieval town.

The heart of Saint Dié consists of four orthogonal spaces occupying "action fields" of volumes, like in Mundaneum (1929): the tower of the administration center which plays a role of urban landmark, cafeterias and common house like social center, the space of the museum of knowledge like a cultural center and one of the accommodation facilities like a place of tourist reception.

The architectures present in the project are also a kind of anthology of the works by Le Corbusier gathered together for this occasion of urban design. The urban planning is based on the decisive role of the architecture and on a harmonic composition of architectural pieces disposed according to a calculated "visual acoustic" (Le Corbusier 1954: 46). The composition restores a dynamic balance between parts and pieces able to re-connect the past to the present, the masses with the voids, the settlement with its own environment in a heterogeneous continuity. It creates a plastic space: a space that can be called "espace indicible" (Le Corbusier 1946b) generated by union of arts.

"[...] Perhaps [...] the approaches to a synthesis. Man quits his melancholy, and turning away from misadventure, creates harmony; unity of Man in his shell; of the earth and his buildings; the individual and the community; man, nature, and the cosmos" (Le Corbusier 1947: 12-13).

The space of new urban design is a place where the unity of ensemble is obtained by the narrativity of visual frames.

The phenomenological aspects are essential in the design process and in the urban experience: the city is a landscape in a specific territory (Fig. 5). "Environment and landscape exist only through the eyes" (Le Corbusier 1997: 80): they enter in the city or constitute a figurative and spiritual element of it.

The project for Saint Dié, as well as later other project, like the center of Bogotà par example, is a composition of permanences from the past, from the landscape and from cultural mnemonic references. Each piece refers to a different totality: "each thing is a whole and yet is only a fragment" (Le Corbusier 1961a: 53).
The iconic global unity of the city is lost, but also rebuilt as a dynamical unity according to changing perceptions.

\section{References}

Cappiello, V. 1989. Le Corbusier ed i centri minori, in V. Leggieri (Ed.). Alla ricerca di Le Corbusier. Napoli: CUEN.

Colli, L. M. 1987. La conversazione con le proprie immagini, Casabella 531-532: 64-73.

Croset, P. 1987. Occhi che vedono, Casabella 531-532: 4-7.

Gans, D. 1999. Foreword in Le Corbusier. Talks with students. New York: Princeton Architectural Press.

Gerosa, P. G. 1978. Le Corbusier, Urbanisme et mobilité. Basel Stuttgart: Birkhäuser.

Eco, U. 1962. Opera aperta. Forma e indeterminazione nelle poetiche contemporanee, Milano: V. Bompiani e C.

Etchells, F. 1987. Introducion in Le Corbusier 1929. The city of to-morrow and its planning. New York: Dover Pubblications.

FLC (Fondation Le Corbusier, Paris Archives). Urbanisme Saint Dié (France). H3-18.

Le Corbusier. 1925. Urbanisme. Paris: G. Crè.

Le Corbusier. 1941. Le quatrês route. Terres, air, fer, eau. Paris: Gallimard.

Le Corbusier. 1945a. Un plan pour Saint-Dié, L'Homme et l'architecture 5-6 Novembre-Decembre.

Le Corbusier. 1945b. Les Trois établissements humains. Paris: Collection ASCORAL Éditions Denoël.

Le Corbusier. 1946a. Un piano urbanistico per Saint Dié, Metron 6 (gennaio): 45-52.

Le Corbusier 1946b, l'Espace indicible, L'Architecture d'Aujourd'hui, special number "Art”, Avril: 9-17.

Le Corbusier. 1946c. Euvre Complète 1938-1946. Zurich: Les Editions d'Architecture Erlenbach.

Le Corbusier. 1946d. A Plan for Saint-Dié, Architectural Record 100: 79-82.

Le Corbusier. 1946f. Manière de penser l'urbanisme. Paris: Éd. de l'Architecture d'Aujourd'hui.

Le Corbusier. 1947. Concerning town planning. Clive Entwisle, London: The Architectural Press.

Le Corbusier. 1951. Proporzione e tempi moderni, in R. Tamborrino (Ed.). 2003. Le Corbusier. Scritti. Torino.

Le Corbusier. 1954. Il cuore della città punto d'incontro delle arti. Acustica visiva in E. N. Rogers, J. L. Sert, J. Tyrwhitt (Eds.). CIAM 8. Il cuore della città: per una vita più umana delle comunità. Milano: Hoepli.

Le Corbusier. 1960. Mein Werk. Stuttgart: Verlag Gerd Hatje.

Le Corbusier. 1961 [1945]. L'urbanistica dei tre insediamenti umani. Milano: Etas Kompass.

Le Corbusier. 1961 [1943]. Talks with students. New York: Orion Press.

Le Corbusier. 1963. Carnet T 70, n.1038, 15 agosto 1963

Le Corbusier. 1997 [1965]. Maniera di pensare l'urbanistica. Roma - Bari: Laterza.

Leggieri, V. (Ed.) 1989. Alla ricerca di Le Corbusier. Napoli: CUEN. 
Musée de Saint-Dié. 1987. Le Corbusier et Saint-Dié. Saint-Dié: Musée municipal de Saint-Dié.

Rogers, E. N.; Sert, J. L.; Tyrwhitt, J. (Eds). 1954. CIAM 8. Il cuore della città: per una vita più umana delle comunità. Milano: Hoepli.

Secchi, B. 1989. Un progetto per l'urbanistica. Torino: Einaudi.

Sert, J. L.; Léger, F.; Gieidon, S. 1993. Nine points of monumentality, in J. Ockman (Ed.). Architecture culture 1943-1968: a documentary anthology. New York: Rizzoli.

Tamborrino, R. 2003. Le Corbusier e gli spazi del contemporaneo, in R. Tamborrino (Ed.) 2003. Le Corbusier. Scritti, Torino: Einaudi.

Vidler, A. 2010. The idea of unity and Le Corbusier's urban form, in A. Vidler (Ed.). The scenes of the streets and other essays. New York: Monacelli Press.

\section{FABIOLA GORGERI}

$\mathrm{PhD}$ in architecture and collaborates in the research and teaching about architectural and urban design at the Department of Architecture (DIDA) of the University of Florence. She is interested in architectural languages and their influence in the urban and territorial transformations. She has done researches about this topics and the heritage of the twentieth century, on which organized seminars and conferences and wrote several essays.

Her latest book Frammenti in architettura. Durata e mutamento da Le Corbusier a João Louis Carrilho da Graça. 